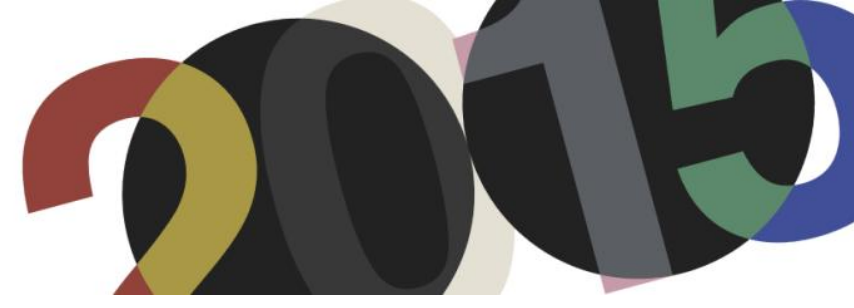

DOI: http://dx.doi.org/10.4995/LC2015.2015.937

\title{
Le Corbusier and São Paulo - 1929: Architecture and Landscape
}

\author{
G. Pianca \\ Faculdade de Arquitetura e Urbanismo da Universidade de São Paulo \\ (Faculty of Architecture and Urbanism of University of São Paulo)
}

\begin{abstract}
This article looks into Le Corbusier's urban proposal for the City of São Paulo, as formulated during his journey to South America in 1929. It highlights the relationship between Architecture and Landscape exposed by Le Corbusier's plan. This paper sets out to investigate the analysis that the innovative Swiss architect performed of the geography and morphology of São Paulo. It contrasts to the works and plans carried out by technicians and engineers at that time.

In order to explain how Le Corbusier's treatment of nature and landscape differs from them, we study the extent to which Le Corbusier's plans show design approaches, which were unusual in terms of Western History and Memory. He also looks into the relationship between Le Corbusier's work, on the one hand, and new technological elements and changes in the visual culture at that time, on the other hand, thus seeking to highlight certain obscure spots within Le Corbusier's work.

This study aims at bringing forward some speculations and methods present in the work of Le Corbusier on cities. It deals with contradictory aspects in Le Corbusier's work in order to deepen our understanding of contemporary urban problems.

Resumen: Este artículo investiga la hipótesis de proyecto de Le Corbusier para la ciudad de San Pablo, propuesta durante su viaje a América Latina en 1929, focalizando en las relaciones entre arquitectura y paisaje. La primera cuestión analizada en este trabajo es el innovador análisis de la geografía y la morfología de San Pablo propuesto por el arquitecto suizo, que contrasta con la manera con que los técnicos e ingenieros locales desarrollaban sus propuestas en ese momento.

Para explicar dicha diferencia en la manera de lidiar con la naturaleza y el paisaje, el autor de este articulo estudia como el trabajo de Le Corbusier presenta abordajes de proyecto inusuales para la Historia y la Memoria, y su relación con los nuevos elementos tecnológicos y de la cultura visual de la época, procurando así resaltar ciertos puntos oscuros en el trabajo del arquitecto. Esta discusión intenta cuestionar ciertas especulaciones proyectuales y metodologías de trabajo presentes en el trabajo de Le Corbusier sobre ciudades, utilizando sus aspectos contradictorios como modo de profundizar nuestro entendimiento de los problemas urbanos contemporáneos.
\end{abstract}

Keywords: Modern Architecture; Modern Urbanism; Landscape Architecture; Le Corbusier; São Paulo. Palabras clave: Arquitectura Moderna; Urbanismo Moderno; Arquitectura Del Paisaje; Le Corbusier; São Paulo.

\section{Introduction}

This article investigates Le Corbusier's project for São Paulo, conceived during his visit to South America in 1929. ${ }^{1}$ The plan opens a dialogue between Architecture and Landscape, seeking to bring new components to the

\footnotetext{
${ }^{1}$ A considerable number of surveys, monographs and theoretical reflections about Le Corbusier's journey to Latin America have being carried out since mid-eighties. Among them, it is worth highlighting the pioneering work of Pereira, Margareth Campos da Silva; Santos, Cecília Rodrigues dos, Le Corbusier and Brasil. São Paulo: Tessela/Projeto, 1987. The following works are also worth of mention: Martins, Carlos F., Razón, ciudad y naturaleza. La génesis de los conceptos en el urbanismo de Le Corbusier. Doctoral thesis. Director: Adolfo Gonzalez Amezqueta. Escuela Técnica Superior de Arquitectura de Madrid. Madrid, 1992; the conference: Tsiomis, Yannis (editor). Le Corbusier: Rio de Janeiro, 1929-1936. Rio de Janeiro: Centro de Arquitetura e Urbanismo do Rio de Janeiro/Prefeitura da Cidade do Rio de Janeiro, 1998; and the recent exhibition of the drawings and sketches of Le Corbusier's Conference in South America: Queiroz, Rodrigo; Segawa, Hugo, Le Corbusier, América do Sul, 1929. São Paulo: Mariantonia - Centro Universitário USP, 2012. In addition to these,
} 
debate on the architect's urban visions, as well as to establish the extent to which changes occurring in technology during the twentieth century would have impact on the work of the architect.

We attempt to reconstruct the project's imagery in conjunction with the material conditions of its formulation, and through three research sources. The first is the historical survey of the existing projects for the city of São Paulo. It reveals the urban and social problems that the city was undergoing. Moreover, the facts showed in the survey serve as a means of comparison with the aims of Le Corbusier's hypothesis. Second, the analysis of historical references that Le Corbusier lists on the project's description - such as the aqueduct of Segovia and the Pont du Gard - is relevant to understand why and how these infrastructural elements are present in the plan. Finally, the analysis of the technical and poetic function of the aerial view in the elaboration process of Le Corbusier's plan inscribes this project in a complex visual culture that was being established at that moment.

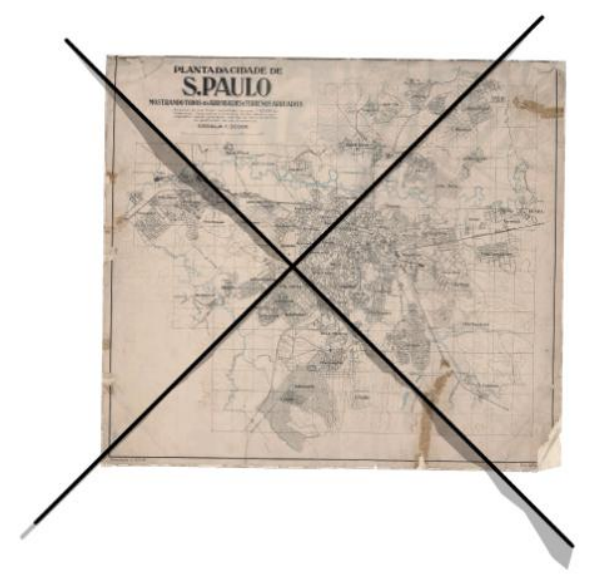

1. Montage of Le Corbusier's plan for São Paulo on cartography, dated from 1924.

The innovative aspects of Le Corbusier's approach to São Paulo are to be found on the radical distinction between traffic routes and water courses. This distinction establishes a relationship of independency between the geomorphology of the circulation system and its buildings. It ascribes to nature a value of enjoyment. It shows the considerable effort of the Swiss architect to recreate signs of great civilizational value, in which diachronic times - the age of the Ancient world and the age of the machine - are combined, in an attempt to reconcile an urban Poieses with the challenges inaugurated earlier in the century. The relationship between Le Corbusier and the aeronautical culture is brought about; it plays a major role in the combination of these two aspects aforementioned. Thereby, it is also necessary to make general characterizations of the period between wars, when this voyage took place. This time embraces a series of social and cultural transformations. The architect was remarkably aware of them, taking part in their debates and undergoing their consequences. Le Corbusier was tracking the development of aviation technology and its use in flightseeing. He was particularly interested in the changes occurring in the relationship between man and its environment, in the new ways for analyzing and understanding territory. ${ }^{2}$ These project characteristics are remarkable in certain later works by Le Corbusier, but they do not remain constant throughout the architect's work.

the recent effort to understand the role of Landscape in Le Corbusier's universe: Cohen, Jean-Louis (editor). Le Corbusier An Atlas of Modern Landscapes. Londres: Thames \& Hudson, 2013.

${ }^{2}$ See Morshed, Adnan, "The Cultural Politics of Aerial Vision: Le Corbusier in Brazil (1929)", in Journal of Architectural Education (1984-), vol. 55, n. 4 (May, 2002), pp. 201-210. 
The great influence of this plan and of other studies to America is generally recognized within authors on the history of architecture. Those plans are circumscribed in a turning point in the trajectory of Le Corbusier, marked by the contrasting directions of the Swiss architect regarding the functional trend of the New Objectivity. It is a widely known fact that Le Corbusier did not attended the II CIAM; instead, he travelled to Latin America, thus allowing himself some valuable time for reflection and research. This moment would be characterized by the radicalization of certain aspects of his thought and practices towards a more sensitive architecture and urbanism, ${ }^{3}$ much closer to the perception of landscape and advocating a broader relation between architecture and nature. ${ }^{4}$ In these plans for the cities of Montevideo, Buenos Aires, São Paulo, Rio de Janeiro, and in the final experience of the "Plan Obus" for Algiers, Le Corbusier formulates, according to some historians such as Manfredo Tafuri, the highest theoretical hypothesis of modern urbanism, one that has not been ideologically or formally surpassed by any other. ${ }^{5}$ Challenging the achievements of Taut, May, Gropius, the Swiss interrupts the continuous sequence architecture-neighborhood-city: the urban structure as such - as a physical and functional unit - is the repository of a new scale of values. And the scope in which these projects are to be understood is the landscape scale.

\section{Le Corbusier's Hypothesis for São Paulo}

A brief introduction to the further description and characterization of Le Corbusier's hypothesis for São Paulo should mention the profound changes the city was undergoing during the first decades of the twentieth century. 1929, the year when Le Corbusier visited São Paulo, is the iconic, exact moment when the contradictions triggered by this process were at full potential.

In 1900, the city of São Paulo can be described as a medium-scale village, with a population of 240,000 inhabitants. Its main economic activity was to serve as a trading post, chiefly for the coffee production in the countryside, and its transport to the port of Santos. During the first decades of the twentieth century, São Paulo turned into an industrialized city; its population increased, amounting to 840,000 inhabitants in $1930 .{ }^{6}$ This steep rise was accompanied by a urban crisis: increasing problems related to traffic and public transportation, the urbanization of areas outside the boundaries of the historic center, increasing sanitation and health problems. However, by that time, public authorities were still formulating their instruments to control these uttered issues .

\footnotetext{
${ }^{3}$ Le Corbusier, "Comotions Sudamericaines. Introduction à un urbanisme sensible”, in La Ville Radieuse. Eléments d'une doctrine d'urbanisme pour l'équipment de la civilisation machiniste. Paris: Ed. L'Architecture d'Aujourd'hui, 1935, p. 220.

${ }^{4}$ Martins, Carlos A. Ferreira, "Uma Leitura Crítica”, in Le Corbusier, Precisões. Sao Paulo: Cosac Naify, 2004, pp. 268-269.

${ }^{5}$ Tafuri, Manfredo, Projecto e Utopia. Lisboa: Presença, 1985, p. 87.

${ }^{6}$ See: Meyer, Regina; Grostein, Marta Dora; Biderman, Ciro, São Paulo Metrópole. São Paulo: Editora da Universidade de São Paulo/Imprensa Oficial do Estado de São Paulo, 2004.
} 


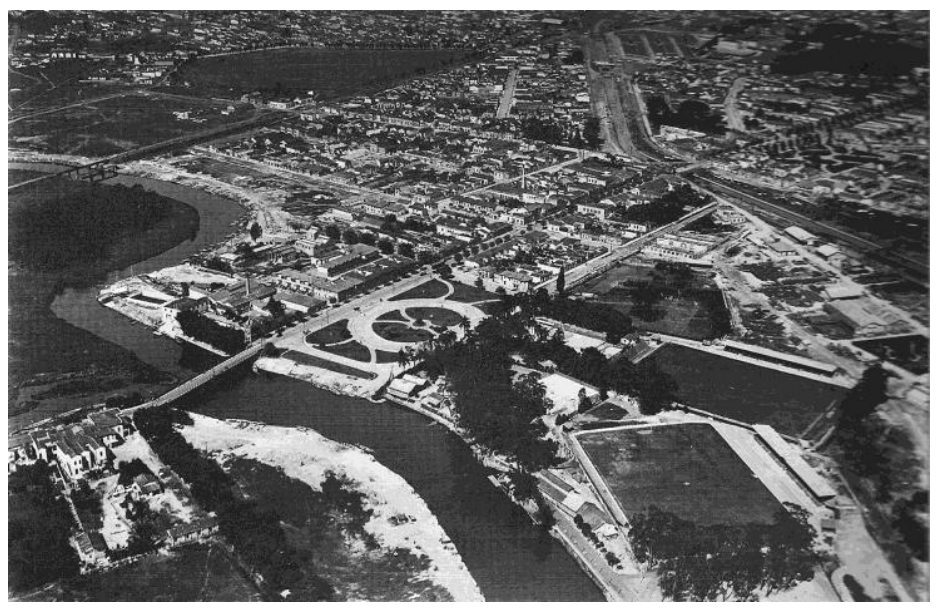

2. Aerial photograph of São Paulo, c. 1930; in the background is Tiradentes Avenue, crossing the now-straightened channel of the Tamanduateí River; in the, foreground the Tietê River follows its original course.

Regarding its physical implementation, the city still consisted mostly of the city's original historic center and its surroundings, limited by the Tamanduateí, the Tietê and the Pinheiros rivers. Beyond these rivers, there were only a few allotments, in which transposition was still precarious. Given these conditions, the city was developing his plans to overcome what would be a major challenge for its growth: the confrontation with its violent hydrography paced by constant floods. ${ }^{7}$

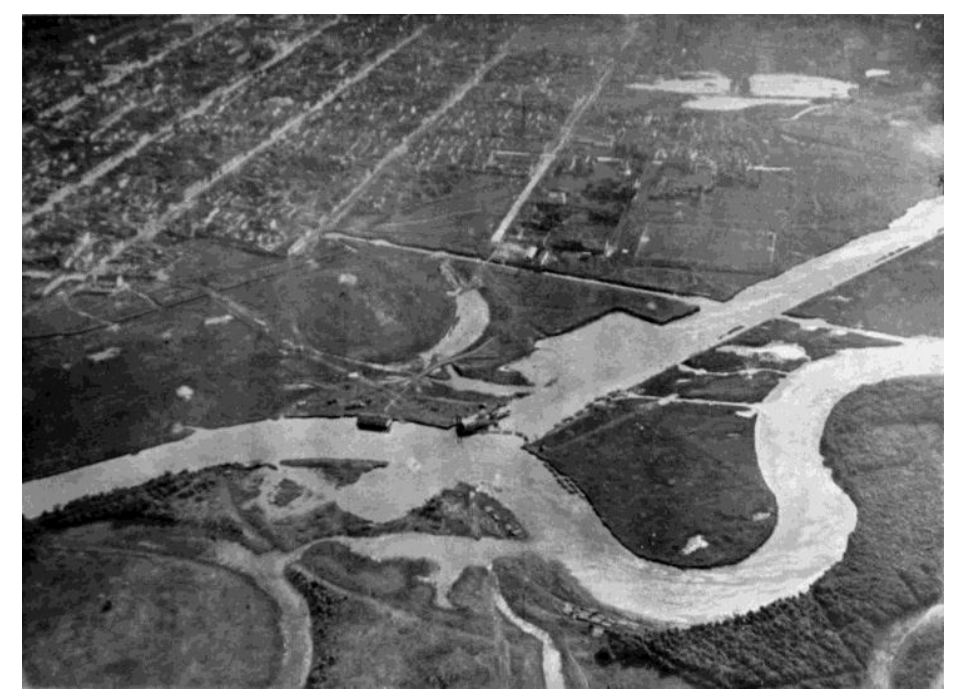

3. The Tietê River's Canalization Process; on the second plan, Bom Retiro district, near downtown, c. 1938.

\footnotetext{
${ }^{7}$ See Seabra, Odette Carvalho de Lima. Os meandros dos rios nos meandros do poder. Doctoral thesis. Department of Geography, FFLCH USP, São Paulo, 1987.
} 
Notoriously, in his text "Corollaire Brésilien", from Precisions, Le Corbusier exposes his perception of the aforementioned conflict:

"Dans le cabinet du préfet de São-Paolo, j'examine avec curiosité, sur le plan mural de la ville, des méandres significatifs. Voici qui est pertinent: ces rues sinueuses passant sous d'autres construites en viaducs. 'Vous êtes', dis-je au préfet, 'en instance de crise de circulation ?'." Le Corbusier ${ }^{8}$

The proposal made by Le Corbusier considered the increasing size of the city of Sao Paulo and its strategic position within the Brazilian territory. It is summed up by two "road axis" set at right angles one to another . One of these axes marks the vector "Rio de Janeiro-Southwest" - connecting the nation's capital at that time. The other axis defined the vector "Northwest-Santos" - the essential link between the coffee production in the countryside and the main port station in Brazil.

Another crucial feature in Le Corbusier's project is the deliverance of transport routes from the crashed topography of the city. It designed these axes as large elevated tracks, able to fully serve the geographical dimension of the city, without deviations or deformations on its course. The main traffic structure of the city would have the physical and material size of São Paulo's landscape:

"Si l'on faisait ceci: poser de colline à colline, de sommet à sommet, une règle horizontale de quarante-cinq kilomètres puis une seconde même règle, à droit à peu prés, pour desservir les autres points cardinaux. Ces règles droites sont les autostrades de grande pénétration en ville, en réalité de grande traversée. Vous ne survolerez pas la ville avec vos autos, mais vous la 'sur-roulerez'. Ces autostrades que je vous propose sont de gigantesques viaducs. Ne faites pas des arches onéreuses pour porter vos viaducs, mais portez les viaducs sur des structures de béton armé qui constitueront des bureaux au centre de la ville et des logements en périphérie. Le cube de ces bureaux et de ces logements sera immense, pris dans l'air du temps; c'est donc une magnifique valorisation. Un projet précis, un édit. Opération déjà décrit.” Le Corbusier ${ }^{9}$

\footnotetext{
${ }^{8}$ Le Corbusier, Précisions sur un état présent de l'architecture et de l'urbanisme. $2^{\text {nd }}$ Edition. Paris: Éditions Vicent, Fréa \& $\mathrm{C}^{\mathrm{ie}}, 1960$, p. 239.

${ }^{9}$ Précisions, op. cit., p. 239.
} 


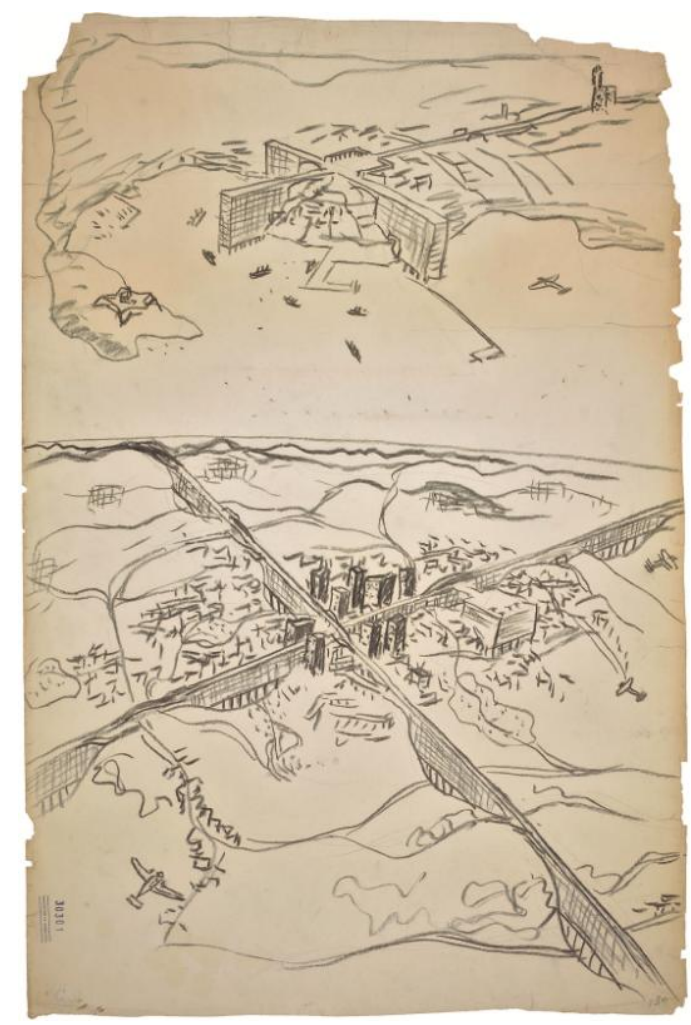

4. Le Corbusier's sketches of his proposals to Montevideo and São Paulo, 1929.

The diagnosis and the proposal for São Paulo present some relevant differences in relation to other urban plans developed on his journey to America. Among four cities, São Paulo is the only one whose picture cannot be grasped from the sea; contrarily to Rio de Janeiro, São Paulo presents no significant topographic component. Due to the fact that the site is marked by a kind of "sea of hills", the recently proper development of the city suggested viaducts as a solution to overcome the numerous small valleys.

In comparison with Le Corbusier's previous formulations, his project for São Paulo has two important distinguishing elements. The first is the removal of the typological difference between the office buildings and residential ones, which now are part of the same macrostructure; the different uses depend solely on the location. Secondly, artificial terrains are no longer created outside the boundaries of the pre-existing city, contrarily to Buenos Aires or Montevideo or to the demolition of a concentrated area, as in the "Plan Voisin" for Paris. ${ }^{10}$

The plan for São Paulo signals a milestone in the transition that the work of Le Corbusier was undergoing in South America. Following a progressive development of the city's abstraction ${ }^{11}$ - in the sense that the urban structure of Buenos Aires deserves a more or less detailed analysis, the interpretation of Montevideo is deducted from the previous one, and the understanding of São Paulo is limited to the verification of the verticalization of the city center and the subtle nuances of the city's geomorphology -, the perspective of Rio de Janeiro seems to be the limit of this process, where nature with its vigor and strength dictates the rhythm and geometry of architecture, paving the way for the subsequent formulation of the "Plan Obus" - the ultimate rupture with the German lines of Architecture and Urbanism.

\footnotetext{
10 "Uma Leitura Crítica", op. cit., p. 285.

${ }^{11}$ Ibid, p. 285.
} 
In São Paulo, the architect cannot avail himself of any sublime horizontal lines in the landscape, any promontories nor any spectacular view of mountains and seas. What is left out to him is the cosmic connection of a large cross, organized by cardinal points. The innovation of this vis-à-vis the previous plans of his journey appears in those gigantic "rules of 45 kilometers" that is not only designed to accommodate business center's offices, but also the residential units in the periphery. This feature anticipates the proposals for Rio de Janeiro and Algiers.

The plan's gigantic dimensions were an innovative aspect of the project, contrasting with the previous project made by the Municipality of São Paulo. In opposition to Le Corbusier's plan, which defines a unity among different territories, such as the floodplains and the top hills, these projects for São Paulo focused primarily on particular issues. They lack a systematic approach. Before looking closely into the relevant and specific elements of Le Corbusier's hypothesis for São Paulo, it is necessary however to look back and make a brief retrospective of the projects that the government of this city had designed to its territory.

\section{São Paulo's problems as seen by local engineers}

São Paulo's engineers were on the margins of the aesthetic debate on the recently inaugurated process of modernization taking place Brazil. Their research and work were associated with the rectification of the Tietê River, carried out in the last decades of the nineteenth century to revert the deterioration of the sanitary conditions of the river's floodplains. It was required due to the critical situation brought about by seasonal floods and especially by the increasing pressure to incorporate new land stocks for the city's expansion. ${ }^{12}$

Given the need to understand the concerns of the engineering in São Paulo, some of these plans will soon be presented. We seek to establish a common genealogy among them regarding the understanding of floodplains as a subject to be dominated by technology, albeit there are considerable differences in landscaping treatment among such studies. It is noteworthy that part of the period when these projects were conceived coincides with the formative years of Le Corbusier and with his early readings about urbanism: many books that the young Charles Eduard Jeanneret consulted in the Bibliothèque nationale of Paris ${ }^{13}$ were read by this generation of Brazilian engineers and laid in the libraries of the Polytechnic Schools. ${ }^{14}$ Some of these books are Der Städtebau by Hermann Josef Stübben, and L'Esthetique des villes by Charles Bulls. Both authors notably played a significant part in the establishment of the theoretical grounds for state engineering in the early twentieth century.

Dating back from the late nineteenth century and the twentieth century, these plans originally aimed at solving sanitation problems. They also attempted to rectify the river, by increasing its steepness and, consequently the speed of the flow of water. It would be an attempt to ward off the sewage from the city's fringes, and to avoid stagnation of water in the urbanized area. Finally, the project conceived the creation of traffic routes adjacent to the canal - in order to deal with the inconstancy of the river. ${ }^{15}$

\footnotetext{
${ }^{12}$ Seabra, Odette, op. cit.

${ }^{13}$ Tafuri, Manfredo, "Machine et mémoire: la ville dans l'oeuvre de Le Corbusier", in. Lucan, Jacques (editor), Le Corbusier une encyclopédie. Paris: Centre Georges Pompidou, 1987, p. 464.

${ }^{14}$ Simões Junior, J. G., "A urbanística germânica (1870-1914). Internacionalização de uma prática e referência para o urbanismo brasileiro", in Arquitextos, Portal Vitruvius. v. 97. São Paulo:

online [http://www.vitruvius.com.br/revistas/read/arquitextos/09.097/134], 2008, pp. 1-11.

${ }^{15}$ For a preliminary research on the projects for São Paulo: Leme, Maria Cristina da Silva (editor), Urbanismo no Brasil. 1895-1965. São Paulo: FAUUSP, FUPAM, 1999.
} 
In 1887, engineer Bianchi Bertoldi conceived the first rectification project for the Tietê and the Tamanduateí Rivers, during the government of President of the Province Visconde de Parnaíba. In 1894, engineer João Pereira Ferraz, through the newly established Comissão de Saneamento do Estado de São Paulo (Sanitation Commission of the State of São Paulo), disposed of the earlier study as a basis for his plan. This project was accomplished thanks to the aid of the first observations and measurements of the river and also to the first accurate topographic surveys of wetlands executed by the Comissão Geográfica e Geológica de São Paulo (Geographical and Geological Commission of São Paulo). The constant threat of floods and pests prompted the first stages of civil work, rectifying three kilometers. However, in 1898 this Commission was extinguished and the works were suspended.

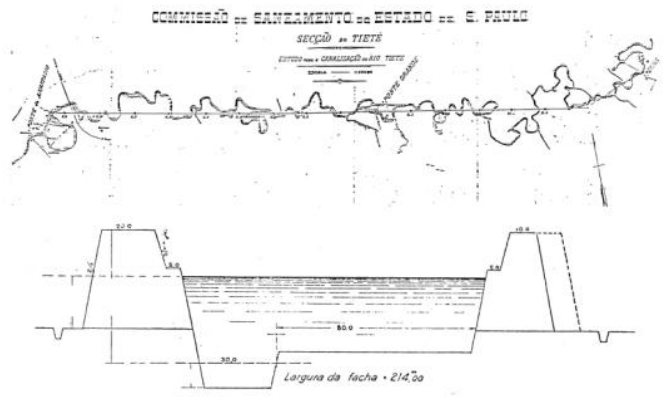

5. Tietê River's channel Section, Eng. João P. Ferraz, c. 1894.

After a long break, engineer Pacheco e Silva make a new proposal to the Municipality in 1913. In the urban field, the Municipality showed more concern with the central area of the remodeling works in the city than with the floodplains, which was still partially occupied by the lower social strata. Only in 1922, a professor of the Polytechnic School on the chair of Ports, Rivers and Canals, professor Fonseca Rodrigues, takes up projects for the rivers, in response to a request made by the Diretoria de Obras Municipais (Municipal Works Agency).

Rodrigues project consisted of two parallel side embankments with waterproofing treatment throughout almost the entire channel length. The space between these embankments measured 108 meters, and its high was 4.5 meters; at their summits two 20-meter wide avenues were planned to be built. Engineer Rodrigues' project was criticized by engineer Victor da Silva Freire, director of the Municipality's Departamento de Obras (Department of Works). According to his argument, the proposal only outlined the hydraulic solution in general terms, and disregarded aspects of the city's embellishment. Engineer João Florence Ulhôa Cintra presented a new plan, focusing on urban embellishment requirements. According to the plan, the height of the dikes is demoted and the width of the largest riverbed is increased; public spaces are placed along riverbanks, and the new channel is set within wide parkways.

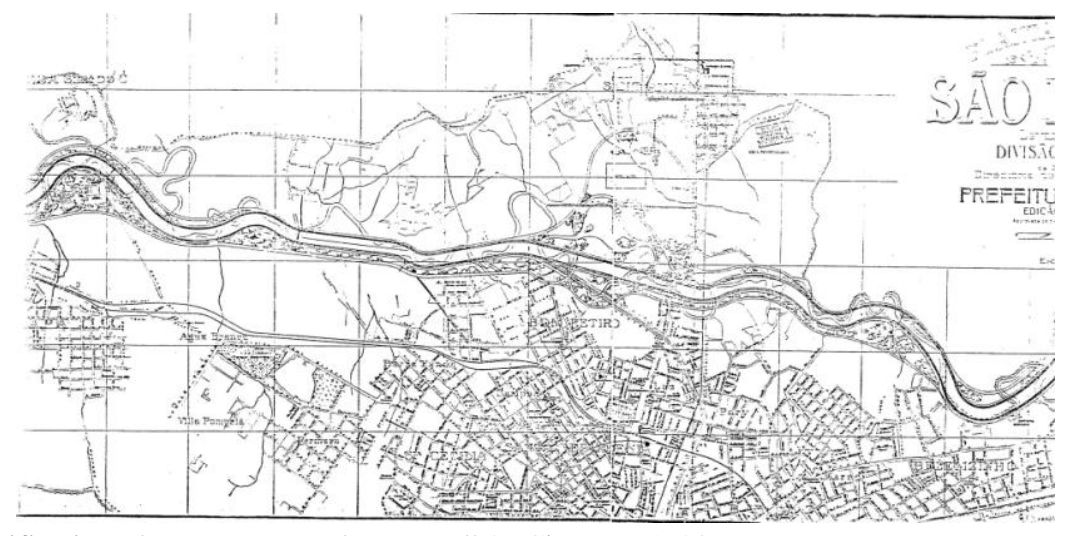

6. Tietê River's Rectification Plan, Eng. João Florence Ulhôa Cintra, c. 1923. 
Two years later, engineer Saturnino de Brito's project combined embellishment criteria and technical aspects with greater maturity and clarity. His plan proposed the increasing of the flow section; the embankment of the lowest areas of margins, which would enable the incorporation of $25 \mathrm{~km}^{2}$ of wetlands into the city; the configuration of two large lakes with a surface of $1.2 \mathrm{~km}^{2}$, which would provide land for landfills and contribute, with its liquid surfaces, to urban embellishment and aquatic sports within the city.

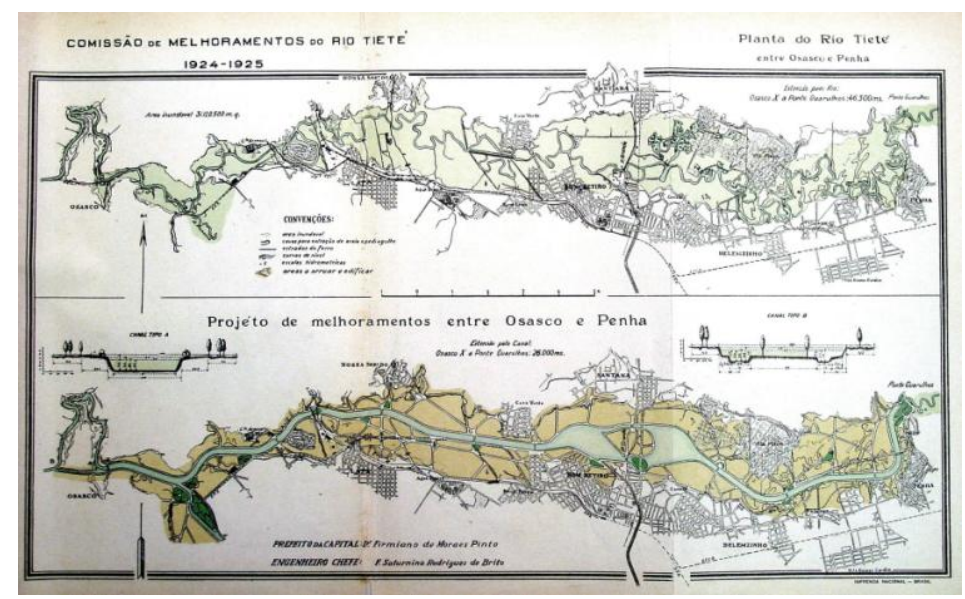

7. Eng. Saturnino de Brito's plan to the Tietê River, c. 1925.

It is remarkable that since 1913 the implementation of marginal avenues around the Tietê River can be seen on these plans. It points out to a major concern with the traffic within the urban debate, and also to the fact that the wealthier classes favored cars. In order to tackle traffic problems, congestion and pedestrian accidents, which could be seen in the city in the twentieth century, Francisco Prestes Maia and Joao Florence Ulhôa Cintra were commissioned by the Municipality to carry out another study.

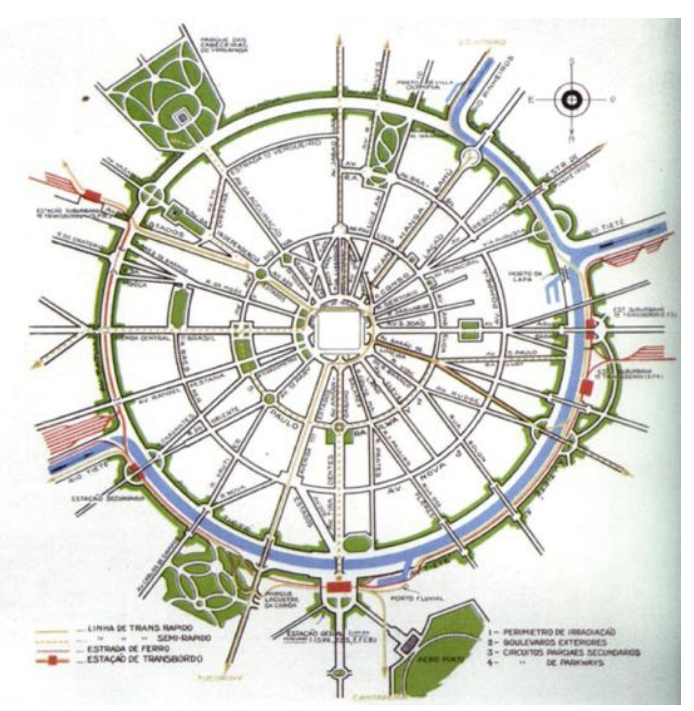

8. Theoretical scheme for Study of a Plan of Avenues to São Paulo, by Prestes Maia and Ulhôa Cintra, c. 1930.

In 1930, the Estudo de um Plano de Avenidas para a Cidade de São Paulo (Study of a Plan of Avenues to the City of São Paulo), as its name implies, combines urban planning issues and the design of avenues, thus highlighting circulation problems as the major urban issue. It considers rivers and nature as nothing else but obstacles to "progress". This plan, unlike the previous ones, was followed by the government and ended up defining the general features of the industrial metropolis into which São Paulo would be turned into in the midtwentieth century. 


\section{Memories of the Past, Memories of Le Corbusier and Memories of the Future}

It is with assertiveness that Le Corbusier conceives the proposal of highways to the plan for São Paulo as well as other proposals for South America and the "Plan Obus". Undoubtedly they can be related to projects like the "Project for Roadtown" by Edgar Chambless, of 1910, to some Russian schemes, and to more specific constructions, such as that by Giacomo Matte-Trucco's in Turin, of 1920-23, with its test course installed on the roof. $^{16}$

The analysis of this constant element found in the Algiers and South American projects usually follows the theoretical lines that regard these highways merely as a futuristic component in these plans. They are associated with the rich collection of historical images and references in Le Corbusier's mind. ${ }^{17}$ The analysis reduces the symbolic value of this component to a pure eulogy of the machine age. ${ }^{18}$ There is still a few analyses that identify the relationship of these highways with monuments of the Western Culture. They see Le Corbusier's project as a parody of a Roman's town diagram on the creation of a cardo and a decumanus, ${ }^{19}$ associating this aspect of the proposal with an imperialist drive to control territories. Rarely it is pointed out that these images and memories of his manifest themselves in certain occasions - thus seeking to create a genealogy of the imagination of these viaducts -, featuring this proposal as a mental dialogue that Le Corbusier has carried out with aqueducts, since his first trip to the East. ${ }^{20}$

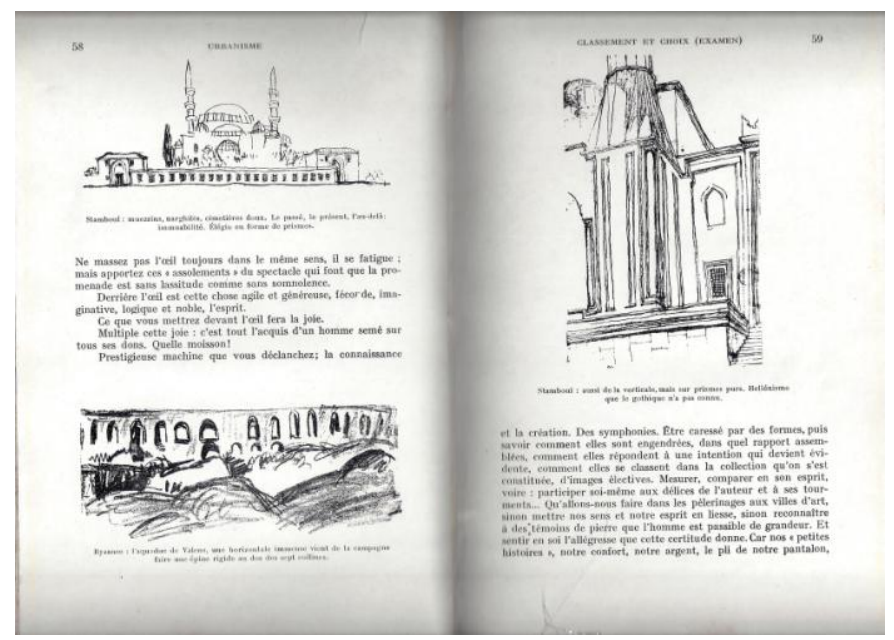

9. Le Corbusier's quotation of Valens on Urbanisme, 1924.

\footnotetext{
${ }^{16}$ Von Moos, Stanislaus, Elements of a Synthesis. Rotterdam: 010 publishers, 2009, p. 199.

${ }^{17}$ Some current research lines seek to associate myths' reconstruction with a fascist tendency within European culture at the beginning of century, which would reverberate in Le Corbusier: Mark Antliff, Avant-Garde Fascism: The Mobilization of Myth, Art, and Culture in France, 1909-1939. Durham, NC: Duke University Press, 2007. For another approach of this subject see the analysis that defines the Swiss architect as a character who cannot renounce the idea that the temporality of the present is not a passageway, but something that remains motionless on the edge of time, getting closer to definitions by Walter Benjamin in Theses on Philosophy of History. See Frajndlich, Rafael Urano, Tafuri: tempo da cidade longínqua, Doctoral Thesis. Director: Mario Henrique D’Agostino. University of São Paulo, Faculty of Architecture and Urbanism, 2014.

${ }^{18}$ Regarding the aforementioned conjunction of highways with buildings, other relevant works deal with this issue: Volker, Ziegler, "Les Chemins de Le Corbusier de l'autodrome à l'autoroute", in: Tsiomis, Yannis (editor), op. cit., pp. 110-115; Weber, Bendicht, "L'architecture d'un viaduc", in Tsiomis, Yannis (editor), op. cit., pp. 64-68.

${ }^{19}$ Oyarzun, Fernando Perez, "Le Corbusier: Latin American Traces", in Cruelty and Utopia. Cities and Landscapes of Latin America. New York: Princeton Architectural Press, 2003, pp. 98-107.

${ }^{20}$ Cabral, Gilberto Flores, "O utopista e a autopista: os viadutos sinuosos habitáveis de Le Corbusier e suas origens brasileiras (1929-1936)”, in Arqtexto, n. 9. Brasil, Porto Alegre: UFRGS, 2006, pp. 54-75.
} 
The attempt to emphasize these images of Antique memories of humanity through the memory and mind of Le Corbusier seems to be required if we need to expand the meanings and reasons of Corbusier's proposal. It is noteworthy to notice that in 1910, in his Voyage à l'Orient, impressed by Valens aqueduct, Le Corbusier drew that monument in charcoal, later including this sketch in Urbanisme, with the caption: "Byzantium: An immense horizontal running through the surrounding country and forming a rigid backbone along the Seven Hills". ${ }^{21}$ The drawing shows to what extent the image of the proposals of 1929 - the viaduct as horizontal joining hills - had been conceived in Le Corbusier's mind, emerging as a manifestation of his creative "subconscious" process that "reused fragments stored in memory for a long time until an opportune resurgence."

Besides the image of the aforementioned Roman aqueduct in Istanbul, in the characterization of the hypothesis for São Paulo the image of two other aqueducts stand out as a synthesis of Le Corbusier's proposal for São Paulo:

"L'aspect magnifique que prendrait tout le site! Quel plus grand aqueduc de Ségovie, quels gigantesques Ponts du Gard! Le lyrisme y trouverait son compte. Y a-t-il rien de plus élégant que la ligne pure d'un viaduc dans un site mouvementé et de plus varié que ses substructures s'enfonçant dans les vallonnements à la rencontre du sol?" Le Corbusier 22

The first ode to Pont du Gard in Le Corbusier's wittings appears in Vers une Architecture, which compares the symbolic value of Pont du Gard with the Pyramids, the Towers of Babylon, the Samarkand Gate, the Parthenon, the Hagia Sophia, the Brunelleschi Cupola, among others. ${ }^{23}$ Below, pictures of the East and the West appear side by side, reinforcing the idea of a slow and suspended temporality as a distinctive trait of Le Corbusier's thought, where these objects are brought back to the present, as if leaps of content were occurring in History.

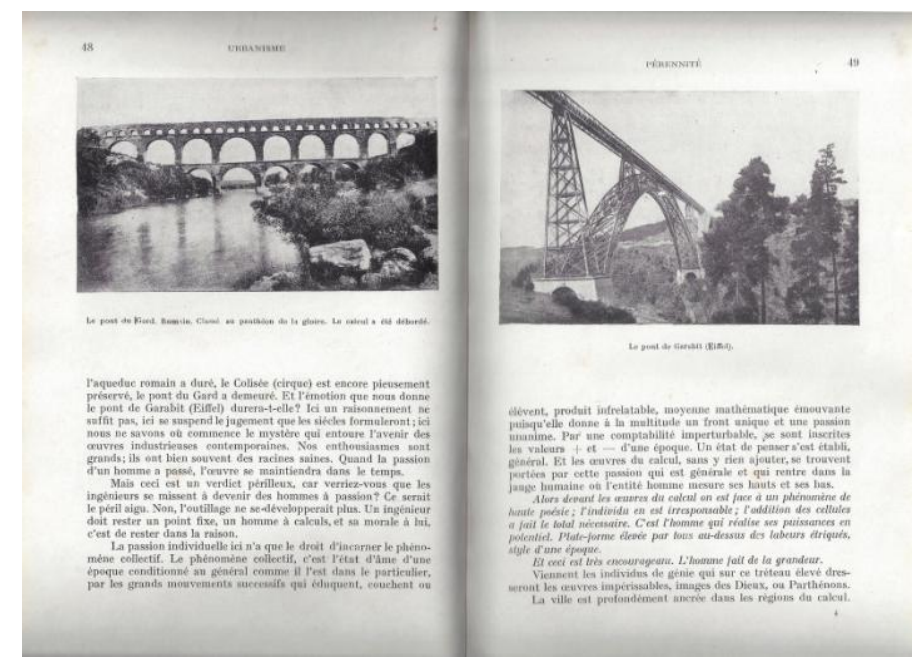

10. Le Corbusier's quotation of Pont du Gard on Urbanisme, 1924.

Besides this aspect, the Pont du Gard represents not only its physical and built limits: it points out to a larger work, the aqueduct of Nîmes, a $50 \mathrm{~km}$ infrastructure built by the Romans as a means of transporting water from a spring at Uzès to the Roman colony of Nemausus. The image of Gard returns in Urbanisme, ${ }^{24}$ now in order to

\footnotetext{
${ }^{21}$ Le Corbusier, Urbanisme. Paris: Editions Crès, 1924, p. 48.

${ }^{22}$ Le Corbusier, "Le Corbusier a Torino" (newspaper interview, 1934), Oeuvre complète, 1929-1934. Zurich: Les Éditions d'architecture Erlenbach-Zurich, p. 202.

${ }^{23}$ Le Corbusier, "Trois Rappels, Le Volume", in Vers une architecture, p. 19.

${ }^{24}$ Urbanisme, op. cit., p. 48.
} 
question the value of masterpieces of modern engineering, and the narrow limits of rationalism that have appeared in the horizon of modernity.

The aqueduct of Segovia, unlike the Pont du Gard, appears as a recent memory of the architect. Le Corbusier visited this Roman aqueduct in Spain during his visit to Madrid in 1928. Initially, this aqueduct did not draw the architect's attention as other works or landscapes did. And it have only been recorded through a postcard that the architect kept in his files together with other postcards, such as the one depicting San Lorenzo Monastery at El Escorial. ${ }^{25}$

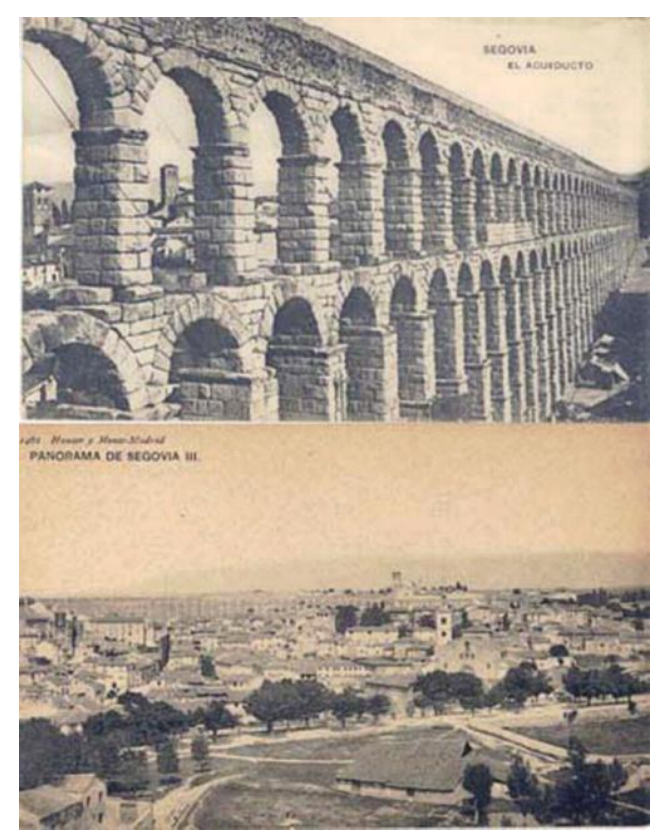

11. Segovia's postcard collected by Le Corbusier on his travel to Madrid and neighboring cities, 1928.

The spatial configuration between the aqueduct and the city in this example reveals the imaginary that Le Corbusier wanted to introduce to the city of São Paulo: in Segovia, the aqueduct and the valley floor form a large-scale free square (Plaza Azoguejo), where its structure turns out to be of great impact. By the hills where the main structure begins, there are two smaller squares serving as a small centrality in opposite sides of the valley (Plaza de Día Sanz to the south, and Plaza del Avendaño to the north), turning the structure into an articulator between sides cut by the primary geography of the place. ${ }^{26}$ The aqueduct stands out as a technique that acts upon nature, without overlapping it. In addition to acting as a vector, the aqueduct rather relates distant geographical points (very similarly to the project for São Paulo), thus seeking its meaning in the territorial aspects of the landscape.

The importance of these aqueducts is remarkable; we believe that it cannot be ignored if we are to achieve a better understanding of these Latin American proposals. As previously mentioned, the proposals underwent a process of abstraction of "urban form" as opposed to the search for a clear and crystalline dialogue with the continental scale that Le Corbusier faces. Aqueducts in this description are appraised by a certain type of

\footnotetext{
${ }^{25}$ An extensive coverage of Le Corbusier's visit to Madrid and its surroundings can be seen in the exhibition catalogue: Guerrero, Salvador, Le Corbusier, Madrid, 1928: Una casa-un palacio. Madrid: Residencia de Estudiantes de Madrid, 2010.

${ }^{26}$ For more information about the Aqueduct of Segovia see: Casado, Fernando C., "Acueducto de Segovia", in id., Acueductos Romanos en España. Madrid: Consejo Superior de Investigaciones Científicas; Colegio de Ingenieros de Caminos, Canales y Puertos, 2008.
} 
reasoning and intelligence: they represent a strong gesture over territory without merely subjugating nature. They express large infrastructure of continental dimensions, detached from the ground and the earth, covering a not obvious but necessary way for the civilizational milestones that Le Corbusier sees in Romans works.

The civilization value that Le Corbusier always attempted to instill in his projects could be achieved through the description of works such as the Pantheon, the Istanbul Monasteries and other architectural icons. It does not even seem reasonable to apply some urban fabric to America. This study seems to be relevant inasmuch it mentions another aspect of ancient civilizations that also fascinated Le Corbusier: the gesture of the aqueduct is the connection between other civilized territories. It represents the founding of new cities and territories. Le Corbusier seems to search for a state of suspension in which memories of the Antiquity and his personal memories are combined, stressing the relationship between present and tomorrow, creating memories of the future.

Le Corbusier seems to grow apart from the objective issues of São Paulo, using the project in an attempt to solve broader problems, instead. He seeks to create a theoretical methodology of approach to the cities, hoping to reconcile the conflict between humanistic values, which he advocates, and the dashing logic of modernity.

What paths Le Corbusier tried to establish? What were the other assumptions and inputs which enabled Le Corbusier to draw such an original plan during his brief stay in São Paulo, greatly different from the ones previously mentioned, conducted by local engineers? What could justify such a lag between Le Corbusier and the contingencies of the city in question?

\section{The plane and the flight of perception}

The problem of the relationship between architect and engineer functions is a constant theme in the writings of Le Corbusier during the 1920s. Both Vers Une Architecture and Urbanisme are marked by a strong conflict between the purposes of the work of engineers, which Le Corbusier admires, and the aim of arousing the emotion that architects seemed very far from inspiring in their works at that time. ${ }^{27}$ According to him, a new historic moment would be founded when sentimental impulses would be identical to those of reason. He argues that modern industrialism would be the result of abstract reasoning, not of passion, for this process no longer would meet the needs of the "great men" but the limited objectives of the "little men". He claims that this simple opposition between the man of science and the poet is rather illusory, and that the poet must accept and celebrate the end products of this "man of poor fortune", the engineer. ${ }^{28}$

It's possible to state that the "Plan Voisin" did not seek to ultimately solve the problems of the modern city, but rather to raise to a certain level the debate on the topic, thus adhering to the spirit of the time, revealing a certain pessimism regarding the fulfillment of its proposals. Hence, these urban plans by Le Corbusier poses anything but a model in the scientific sense, because they perform a dialectic consisting of the interaction of pragmatism (function) and the ideal order (pure form).

The late twenties and the passage to the thirties is the moment when Le Corbusier radicalized these conflicts, not only theoretically, but also bringing these contradictions into his architectural and urban production. According to Tafuri, this external contradiction becomes internal in Le Corbusier's design for the Apartament of Beistegui. In this project, the Swiss becomes "haunted by metaphorical concerns that come together in a 'open room". Its

\footnotetext{
${ }^{27}$ Colquhoun, Alan, "Arquitetura e Engenharia: Le Corbusier e o paradoxo da razão”, in Modernidade e Tradição Clássica. São Paulo: Cosac Naify, 2004, p. 110.

${ }^{28}$ Urbanisme, op. cit., p. 48.
} 
language tries to reconcile technical and natural features. For the Roman historian, this project refuses both the existing Paris and the Ville Radieuse, where its language and images are transferred to the field of metaphors and dreams. So Tafuri recreates this internal contradiction in the work of Le Corbusier with the question of how to reconcile this poiesis to the needs imposed by the terrestrial myth of rationalization. ${ }^{29}$

To Le Corbusier it seems that what was in question was how to handle the urban phenomenon and its problems, but above all, how to perceive the cities of his epoch sensitively enough, thus rewriting the fundamental questions of urbanism. Notoriously, in the Beistegui's terrace project, the distance interposed between the penthouse and the Parisian panorama is ensured by a technological device, ${ }^{30}$ indicating some hope for the sensitive and poetic use of certain tools and technological possibilities, which could, even in the field of the metaphor, reconcile the conflict mentioned above. The articulating function between the architect and the citylandscape, the instrument-periscope performed in the project for Beistegui, would be reconstituted through the use of aerial view on his journey to South America.

The impact of the incorporation of the aerial view on the imaginary of modernity was notable. For signs of this aerial modernity, we can consider Friedrich Nietzsche's clarion call on Thus Spoke Zarathustra to "kill the Spirit of Heaviness". The personalization that Nietzsche held of this phenomenon brings to mind a set of antinomies, such as light and heavy, air and ground, or even air and space, antinomies that highly pervade a culture of many modern vanguards. ${ }^{31}$ These processes can be seen as creating a new time, as described by Nietzsche, a process able to refund even the name of the Earth: "He who will one day teach men to fly will have moved all boundarystones; all boundary-stones will themselves fly into the air to him, he will baptize the earth anew - as 'the weightless'., ${ }^{32}$ This approach have many similarities to the way Le Corbusier will work at different times on his writings, as we can find on his remark that airplanes are a "sign of new times" advancing forward "in a winged flurry". 33

For some specialists in the visual culture of the aerial view, as Davide Deriu, the practice of modern flight therefore signaled the last escape from the labyrinth of the modern city. The ascent of the planeur, in his words, was implied in the dialectics of spectacle and surveillance: on the one hand, the aerial observation participated in a civilization increasingly mediated by independent representation; on the other hand, it was instrumental to the disciplinary mechanisms of visual detection and inspection. ${ }^{34}$ Certainly both of these aspects can be retained in the thought of Le Corbusier, but above all, the first aspect is more characteristic and remarkable in his thinking. The architect's understanding of this technological impact on the cognitive system can be framed by what writer Roland Barthes realized later on: "The bird's eye view [...] gives us the world to read not only to perceive; this is why it corresponds to a new sensibility of vision; in the past, to travel [...] was to be thrust into de midst of sensation, to perceive only a kind of tidal wave of things; the bird's eye view, on the contrary, [...] permits us to transcend sensation and to see things in their structure." 35

\footnotetext{
29 "Machine et mémoire", in op. cit., p. 460.

${ }^{30}$ Ibid., p. 460.

${ }^{31}$ Ramirez III, Enrique Gualberto. Airs of Modernity. 1881-1914. Doctoral Thesis. Director: Edward A. Eigen. Princeton University, School of Architecture, 2013, pp. 8-9.

${ }^{32}$ Friedrich Nietzsche, "The Spirit of Gravity", in op. cit., p. 210.

${ }^{33}$ Le Corbusier, Sur les 4 routes. Paris: Gallimard, 1941, p. 125.

${ }^{34}$ Deriu, Davide. "The Ascent of the Modern Planeur: Aerial Images and Urban Imaginary in the 1920s", in Emden, Christian; Keen, Catherine; Midgley, David (editors). Cultural History and Literary Imagination, vol.7; Imagining the City, vol.1. Oxford: Peter Lang, 2006. pp. 189-211.

${ }^{35}$ Barthes, Roland, “The Eiffel Tower”, in Sontag, Susan (editor), A Roland Barthes Reader. London: Vintage, 1993, p. 242.
} 
More than a tool between man and nature, the plane was, for the architect's mind, an object which spirit of creation could be equaled to works of the Western civilization such as the Parthenon: "L'avion a mobilisé l'invention, l'intelligence et la hardiesse: l'imagination et la raison froide. Le même esprit a construit le Parthénon" ${ }^{36}$ During his trip in Latin America, the plane turns into the instrument that allows Le Corbusier to unveil the secrets hidden at ground height. It makes these secrets transparent and leaves those large urban articulations in evidence. Being constituted as a kind of urban inebriation, a vertigo from the heights, in this way it takes hold of Le Corbusier and corresponds, in his city observation strategies, to a second break with the derived method of Camillo Sitte, based on the perspective view, that so much had seduced him, back to 1915 . $^{37}$

As Jean-Louis Cohen points out in his article "L'ombre de l'oiseau planeur", the plane would have been in Le Corbusier's mind a multiple operator, a vector of visual acuity, but also the founder of a civic morality. This urban condenser would have assumed the status of a magical instrument, of a flying camera obscura. It allowed the architect to develop a point of view, which is both material and theoretical, in relation to field of its action and projects. ${ }^{38}$

According to Le Corbusier's hypothesis for São Paulo, the plane is used to attain a new perspective that would allow him to accurately resize and characterize the challenges that the city was facing. Through this visual means to attempt the reconciliation of the contradiction between the constitution of a Poiesis and the terrestrial myth of technology, the Swiss surpasses the theoretical understanding that the set of technicians and local engineers possessed of that territory.

\section{Conclusions}

The innovative and relevant aspects of Le Corbusier's hypothesis for São Paulo are summed up in three items: the accurate understanding of the geomorphology and physical territory of the city, regarding the technical tools and the historic background that local engineers possessed; the radical conjunction of the urban infrastructure, expressed in high freeways, with major uses for the city (housing, services and commerce); at last, the nonbinding of a hallmark of the city, represented through its broad rivers and floodplains, in regard to the set of infrastructure and utility buildings.

This project also refers to to two elements that assemble the foundational imaginary identity of the city of São Paulo, as expressed by the architect:

“Comme des traits, les autos traverseront l'agglomération trop étendue. Du niveau supérieur des autostrades, elles descendront dans les rues. Les fonds des vallées ne seront pas bâtis, mais libres pour le sport et le parquage des autos de petite circulation. Vous y planterez des palmiers à l'abri des vents. D'ailleurs, vous avez déjà créé un début de parc à arbres et à autos au centre de la ville.

Pour vaincre les sinuosités du plateau mamelonné de Saint-Paul, on peut construire des autostrades de niveau, portés sur des gratte-terre." Le Corbusier ${ }^{39}$

\footnotetext{
${ }^{36}$ Le Corbusier. "Des yeux qui ne voient pas... les avions", in Vers une architecture, op. cit., pp. 83-85.

${ }^{37}$ See his manuscript La Construction des Villes, written from 1910 to 1915: Lausanne: L’Âge d'Homme, 1992 (introduction and transcription by Marc E. Albert Emery).

${ }^{38}$ Cohen, Jean-Louis, "L'ombre de l'oiseau planeur", in Yannis Tsiomis (editor), op. cit., 1998. pp. 58-63.

${ }^{39}$ Précisions, op. cit., p. 242.
} 
The primary nature, valleys and rivers, are present in this idea. What is also present in another instance is the domesticated nature, represented through this horizontal ruler, with cars "sur-roulerez" on the highway and buildings being developed according to this plan. It was something very similar to the existing spacial configuration of the Anhangabaú Valley at the time.

In this project, Le Corbusier considers the hydrography a non-productive value, regardless of its major role in leisure. Le Corbusier believes that the vocation of these areas should be associated with the enjoyment of nature. We emphasize that this non-productive character that Le Corbusier ascribes to the floodplain of Tietê is radically distinct from conceptions according to which floodplain rectification projects would be placed on major traffic routes of the city, as shown in the analyzed projects.

This decoupling between floodplains and the city circulation system is paramount in the debate on contemporary urban problems. However distinct the production process and the sphere, means of circulation and its industries are nodal points in the capitalist economy and can be considered the continuation of a production system in and for the circulation process. ${ }^{40}$

The drawing and the building of São Paulo, however, were at odds with the idea of independence between waterways and transport routes: avenues were constructed buffering creeks or rectifying main water courses, associating almost irreversibly the circulation system and the water system, without setting up a system of green areas and leisure. Thus, by combining our rivers and valleys with circulation circuits of goods and capital, we subordinated these natural elements to global processes of the productive system. So, with this close attachment of the circulation process to the production process, in which goods and capital circulation time act as negative limits over the production time, or the amplitude in which a given grandeur of capital functions as a productive capital, always forcing the circulation time so it ideally reaches zero, ${ }^{41}$ São Paulo's history constrained the valleys to be an incessant site of construction of new roads, growing more distant from the primordial aspects of its geography and the former nature in the worst manner.

Le Corbusier's project appears not only as an antipode of the engineering plans of that time, but also of the current situation of São Paulo. His persistent attempt to re-establish the fracture between a poetic vision of the architecture and the aims of technique endures, for almost eighty years since it had first been formulated, as a provocation - a call for reflection on the contemporary city. The reconstruction of the contradictions that lead not only São Paulo but also other cities to the current critical situation, in conjunction with the development of several projects of research that took place, seem to be the way to build a desirable horizon, just as Le Corbusier tried to accomplish.

\section{Source of images}

1. Photomontage, Guilherme Pianca. Cartography of the Urban Development Secretary of the Municipality.

2. Photograph, unknown authorship (A. Salatini private collection), c. 1930. In Reis, N. G, São Paulo: vila, cidade, metrópole. São Paulo: Prefeitura de São Paulo, 2004.

3. Photograph, unknown authorship, c. 1938. In Maria, Francisco Prestes, Os melhoramentos de São Paulo. São Paulo: Prefeitura Municipal de São Paulo, 1945.

4. Drawing, Le Corbusier. Fundação Le Corbusier, Paris. FLC 30301.

\footnotetext{
${ }^{40}$ Marx, Karl, O Capital: Crítica da Economia Política. Livro Segundo - O Processo de Circulação do Capital, Barbosa, Regis; F. Kothe, Flávio R. (transl.). São Paulo: Abril Cultural, 1984, p. 110.

${ }^{41}$ O Capital: Crítica da Economia Política. Livro Segundo - O Processo de Circulação do Capital, op. cit., p. 91.
} 
5. Drawing, João P. Ferraz. In Lysandro Pereira, Relatório: Comissão de Melhoramentos do Rio Tietê. São Paulo: Prefeitura do Município de São Paulo, 1950.

6. Drawing, João Florence Ulhôa Cintra. In Lysandro Pereira, Relatório: Comissão de Melhoramentos do Rio Tietê. São Paulo: Prefeitura do Município de São Paulo, 1950.

7. Drawing, Saturnino de Brito. In Saturnino de Brito, F., Melhoramentos do Rio Tietê em São Paulo: relatório. São Paulo: Governo do Estado, 1926.

8. Drawing, Prestes Maia, 1930. In Toledo, B. L., Prestes Maia e as origens do urbanismo moderno em São Paulo. São Paulo: Empresa das Artes, 1996.

9. Excerpt, in Le Corbusier, Urbanisme. Paris: Editions Crès, 1924.

10. Excerpt, in Le Corbusier, Urbanisme. Paris: Editions Crès, 1924.

11. Postcard, unknown authorship (Le Corbusier's private collection). Guerrero, Salvador, Le Corbusier, Madrid, 1928: Una casa-un palacio. Madrid: Residencia de Estudiantes de Madrid, 2010.

\section{Bibliography/references}

Antliff, Mark, Avant-Garde Fascism: The Mobilization of Myth, Art, and Culture in France, 1909-1939. Durham, NC: Duke University Press, 2007.

Barthes, Roland; Sontag, Susan (editor), A Roland Barthes Reader. London: Vintage, 1993.

Cabral, Gilberto Flores, "O utopista e a autopista: os viadutos sinuosos habitáveis de Le Corbusier e suas origens brasileiras (1929-1936)", in Arqtexto, n. 9. Brasil, Porto Alegre: Universidade Federal do Rio Grande do Sul (UFRGS), 2006.

Casado, Fernando C., Acueductos Romanos en España. Madrid: Consejo Superior de Investigaciones Científicas; Colegio de Ingenieros de Caminos, Canales y Puertos, 2008.

Cohen, Jean-Louis (editor), Le Corbusier - An Atlas of Modern Landscapes. Londres: Thames \& Hudson, 2013.

Cohen, Jean-Louis, "L'ombre de l'oiseau planeur", in Yannis Tsiomis (editor), Le Corbusier: Rio de Janeiro, 1929-1936. Rio de Janeiro: Centro de Arquitetura e Urbanismo do Rio de Janeiro/Prefeitura da Cidade do Rio de Janeiro, 1998, pp. 58-63.

Colquhoun, Alan, "Arquitetura e Engenharia: Le Corbusier e o paradoxo da razão", in Modernidade e Tradição Clássica. São Paulo: Cosac Naify, 2004.

Deriu, Davide, "The Ascent of the Modern Planeur: Aerial Images and Urban Imaginary in the 1920s", in Emden, Christian; Keen, Catherine; Midgley, David (editors). Cultural History and Literary Imagination, vol. 7; Imagining the City, vol. 1. Oxford: Peter Lang, 2006, pp. 189-211.

Frajndlich, Rafael Urano, Tafuri: tempo da cidade longínqua, Doctoral Thesis. Director: Mario Henrique D’Agostino. University of São Paulo, Faculty of Architecture and Urbanism, 2014.

Le Corbusier, Vers une architecture. Paris: G. Crès e Cie, 1923.

Le Corbusier, Urbanisme. Paris: Editions Crès, 1924.

Le Corbusier, Précisions sur un état présent de l'architecture et de l'urbanisme. $2^{\text {nd }}$ Edition. Paris: Éditions Vicent, Fréa \& C ie 1960.

Le Corbusier, Sur les 4 routes. Paris: Gallimard, 1941, p. 125.

Le Corbusier, Oeuvre complète, 1929-1934. Zurich: Les Édition d'architecture Erlenbach-Zurich

Le Corbusier, "Comotions Sudamericaines. Introduction à un urbanisme sensible", in La Ville Radieuse. Eléments d'une doctrine d'urbanisme pour l'équipment de la civilisation machiniste. Paris: Ed. L'Architecture d'Aujourd'hui, 1935.

Martins, Carlos A. Ferreira, "Uma Leitura Crítica”, in Le Corbusier. São Paulo: Cosac Naify, 2004. 
Martins, Carlos A. Ferreira, Razón, ciudad y naturaleza. La génesis de los conceptos en El urbanismo de Le Corbusier. Doctoral thesis. Director: Adolfo Gonzalez Amezqueta. Escuela Técnica Superior de Arquitectura de Madrid. Madri, 1992.

Marx, Karl, O Capital: Crítica da Economia Política. Livro Segundo - O Processo de Circulação do Capital, Barbosa, Regis; F. Kothe, Flávio R. (transl.). São Paulo: Abril Cultural, 1984.

Meyer, Regina; Grostein, Marta Dora; Biderman, Ciro, São Paulo Metrópole. São Paulo: Editora da Universidade de São Paulo/Imprensa Oficial do Estado de São Paulo, 2004.

Morshed, Adnan, "The Cultural Politics of Aerial Vision: Le Corbusier in Brazil (1929)", in Journal of Architectural Education, vol. 55, n. 4, May, 2002.

Nietzsche, Friedrich, Thus Spoke Zarathustra, R. J., Hollingdale (transl.). New York: Penguin, 2003 (1961).

Oyarzun, Fernando Perez, "Le Corbusier: Latin American Traces", in Cruelty and Utopia. Cities and Landscapes of Latin America. New York: Princeton Architectural Press, 2003.

Pereira, Margareth Campos da Silva; Santos, Cecília Rodrigues dos, Le Corbusier and Brasil. São Paulo: Tessela/Projeto, 1987.

Ramirez III, Enrique Gualberto, Airs of Modernity 1881-1914. Doctoral Thesis. Director: Edward A. Eigen. Princeton University, School of Architecture, 2013.

Seabra, Odette Carvalho de Lima, Os meandros dos rios nos meandros do poder. Doctoral thesis. Department of Geography, Faculdade de Filosofia, Letras e Ciências Humanas - Universidade de São Paulo (FFLCH- USP), São Paulo, 1987.

Simões Junior, J. G., "A urbanística germânica (1870-1914). Internacionalização de uma prática e referência para o urbanismo brasileiro", in Arquitextos, Portal Vitruvius, vol. 97. São Paulo: Online [http://www.vitruvius.com.br/revistas/read/arquitextos/09.097/134], 2008, pp. 1-11.

Tafuri, Manfredo, Projecto e Utopia. Lisboa: Presença, 1985.

Tafuri, Manfredo, "Machine et mémoire: la ville dans l'oeuvre de Le Corbusier", in Lucan, Jacques (editor), Le Corbusier une encyclopédie. Paris: Centre Georges Pompidou, 1987, p. 464.

Tsiomis, Yannis (editor), Le Corbusier: Rio de Janeiro, 1929-1936. Rio de Janeiro: Centro de Arquitetura e Urbanismo do Rio de Janeiro/Prefeitura da Cidade do Rio de Janeiro, 1998.

Volker, Ziegler, "Les Chemins de Le Corbusier de l'autodrome à l'autoroute", in Tsiomis, Yannis (editor), Le Corbusier: Rio de Janeiro, 1929-1936. Rio de Janeiro: Centro de Arquitetura e Urbanismo do Rio de Janeiro/Prefeitura da Cidade do Rio de Janeiro, 1998. pp. 110-115

Von Moos, Stanislaus, Elements of a Synthesis. Rotterdam: 010 publishers, 2009.

Weber, Bendicht, "L'architecture d'un viaduct", in Tsiomis, Yannis (editor), Le Corbusier: Rio de Janeiro, 1929-1936. Rio de Janeiro: Centro de Arquitetura e Urbanismo do Rio de Janeiro/Prefeitura da Cidade do Rio de Janeiro, 1998. pp. 64-68. 